\title{
PARADIGM SHIFT: YOUTH ENGAGEMENT IN THE CONDUCT OF THE 2015 ELECTIONS IN NIGERIA
}

\author{
Oarhe Osumah \\ Oarhe Osumah is a lecturer in the Department of Public Administration, \\ Faculty of Management Sciences, Ambrose, Alli University \\ Ekpoma, Edo State, Nigeria \\ email: osumahoarhe@yahoo.com
}

\begin{abstract}
This paper examines youth engagement in the conduct of the 2015 general elections in Nigeria, against a backdrop of historical experiences. Discounting the doom youth theory of youth bulge, youth in crisis or lumpen youth culture, the article illustrates a paradigm shift in youth engagement in the conduct of elections. Youth engagement in the 2015 elections was more constructive than in prior elections. Within the context of dual motivation theory, the destructive engagement by youth in the prior elections was motivated by the need to change the outcome, whereas their constructive conduct in the 2015 elections was driven by duty to participate in public affairs in Nigeria. This change in political attitude is explained by a growing consciousness of the potential of young people to act as agents of change. This awareness arises through the aid of social media, coupled with the recent success story of the Arab Spring driven by youth, the inflammable repercussions of previous elections, and the high stakes the 2015 general elections held for Nigerian governance.
\end{abstract}

Keywords: youth, election, motivation, participation

\section{INTRODUCTION}

Prior to the 2015 elections, there had been a progressive decline in the conduct of elections in Nigeria since the return to civil rule in May 1999. With the exception of the 2011 general elections, which witnessed little improvement, all other elections represented a travesty. This travail of electoral politics in Nigeria prompted 
Agbaje and Adejumobi (2006) to ponder whether votes still counted. In the last decade of electoral politics in Nigeria, the political class had managed to exercise its monopoly over political mobilisation, and undermined popular participation. Public participation was curtailed especially through demobilisation of the youth from constructive political engagement. Through anti-democratic measures, the political class effectively co-opted most of the youth in the country into political engagement, with dire consequences. In Nigeria, the youth population is aged between 18 and 35 years (National Youth Development Policy 2001; Olujide 2008).

Seminal works have been written on youth political engagement in the electoral process in Nigeria. Within this body of studies, there are distinctive works concerned with the dynamic of anti-democratic political attitudes of the youth in Nigeria (Adejumobi 2000; Agbaje \& Adejumobi 2006; Sklar 2004). However, such writings are limited in scope to elections that took place before 2015. Disregarding the traditional youth theory of youth bulge, youth in crisis and lumpen youth culture, this article demonstrates how youth engaged positively in the conduct of the 2015 elections. Compared with earlier general elections in Nigeria's current republic, the 2015 elections have been judged by international and local observers as being most successful. Compared with the previous elections, remarkable improvements were noted in the conduct, outcomes, and management of reactions to the outcomes of the 2015 elections. In particular, the presidential election in 2015 led to the emergence of an opposition party candidate as the winner, with the incumbent and rival candidate conceding defeat even before the final declaration of results by the Independent National Electoral Commission (INEC). The reactions to the outcome of the elections were peaceful - in contrast to those in previous elections, which were marred by post-election violence. Also, unlike past elections wherein gullible youth were manipulated by the political class to play destructive roles (such as election rigging, ballot-box snatching, hooliganism, or intimidation), in the conduct of the 2015 elections the youth undertook various positive initiatives. These included peace campaigns, voter education, election monitoring, and polling unit administration to ensure successful conduct.

This paper also discusses a paradigm shift from the doom youth theory, based on reflections on youth engagement in previous elections, to the notion of positive and constructive youth political conduct before and during the 2015 elections. It seeks to provide explanations for the positive youth engagement within the context of dual political motivation theory, which identifies two bases for political participation (Sika 2012). In the first type of political motivation, political participation is activated by the desire to achieve a certain goal, influencing the outcome of an election, and controlling the actions of governmental personnel. The second motivation is driven by a duty to participate in an electoral process in one's country as a result of acquired social capital. A synthesis of the two 
types of political engagement, in David Campbell's perspective, creates 'a dual motivation theory' (Sika 2012). This theory has not been thoroughly explored to explain youth engagement in the 2015 elections in Nigeria. In an attempt to understand the patterns of youth engagement and motivation in the conduct of the 2015 general elections in Nigeria, this paper proceeds with conceptual and theoretical discussion.

\section{CONCEPTS AND THEORY ON YOUTH POLITICAL ENGAGEMENT}

In Nigeria, the 'youth' population is aged between 18 and 35 years (National Youth Development Policy 2001; Olujide 2008). As in most other countries of the world, young adults constitute a vast proportion of Nigeria's more than 171 million people (UNICEF 2013). Most studies on youth engagement and experiences in African societies have been dominated by the application of the traditional theory of 'youth bulge', combined with 'youth in crisis' and 'lumpen youth culture'. The common denominator of traditional youth theories is a vituperative characterisation of youth, such as 'lost generation' (O'Brien 1996), 'devils in demographic' (Urdal 2004), 'enduring limbo' (Spinks 2002), 'ticking time bomb' (Schucher 2014), 'loose molecule' (cited in Aghedo \& Eke 2013), 'war machine' (cited in Aghedo \& Eke 2013), 'lumpen' (Abdullah \& Muana 1998, Bangura 1997), and 'Frankenstein Monster' (Ukiwo 2002).

The term 'youth bulge' was coined by Gunnar Heinsohn, a German social scientist; it was made popular by Gary Fuller and Jack Goldstone, two American political scientists (Aghedo \& Eke 2013). Youth bulge theory denotes a situation where a country hosts a large population, dominated by young persons who are mainly marginalised, excluded, and deprived in relation to the older adult population. This theory contends that such a large youthful population constitutes a high risk and threat in the country. In other words, a heavy youth population is a predictor of various forms of violence, including rebellion, warfare, criminality and other aggressive behaviour. The Arab Spring and Islamic revivalism that occurred in countries such as Egypt, Tunisia, and Algeria are ascribed to a combination of youth bulge and limited economic opportunities (Aghedo \& Eke 2013).

Youth crisis combines with youth bulge to engender violent and criminal engagements. Youth crisis is a condition in which young people find it difficult to attain the requisite qualities of adulthood because of slim socioeconomic and political opportunities. Youth crisis arises from the irresponsiveness and insensitivity of the national government in addressing young people's genuine needs and aspirations through sound policies and programmes. Thus, in desperation to navigate the difficult path of life, young people engage in aggressive and risky behaviour. In the face of fading hope, they take their destiny into their 
own hands by engaging in various criminal behaviours, including armed banditry, kidnapping for ransom, bunkering, vandalism, and insurgency. ('Bunkering' means stealing fuel oil on board a ship.) The Boko Haram insurgency in northeastern Nigeria is in part linked with scant economic opportunities and access (Aghedo \& Osumah 2014). Abject socioeconomic conditions, manifesting in youth unemployment and poverty, have been linked with ethno-religious conflict in Nigeria (Jega 2007). In Kenya, youth exclusion and marginalisation from the political process is cited as contributing to youth participation in post-election violence in 2007-2008. About 70\% of participants in the post-election violence were young adults (Mutisi 2012).

Another variable that conflates with youth bulge to engender youth engagement in violence and criminality is what Abdullah and Muana (1998) and Bangura (1997) characterise as 'lumpen youth culture'. The lumpen youth culture is a sense of antisocial and anti-establishment orientation. The lumpen youth, which Usman (2009) describes as expendable youth, are young people who are not matured and are materially dependent and susceptible to manipulation. They are characterised as largely unemployed - and unemployable - youth, mostly male, who engage the streets for their livelihood. They are susceptible to be manipulated as an instrument for the perpetration of electoral violence. They act as party thugs and are used by party stalwarts for political violence and criminal activities for a token sum, sometimes a pittance. They are often fed with dangerous drugs and other intoxicants and armed as ruthless agents of destruction. They actively participate in electoral activities that undermine the conduct of credible elections and jolt public confidence in the electoral process.

The traditional or 'doom theory' on youth is dominated by the notion that youth are Frankenstein monsters and victims of electoral violence. The theory tends to play down the distinctive initiatives of young people in the conduct of an election, and electoral change processes in which youth participated. The preponderant notion of youth as 'loose molecules' underestimates the potential and right of the youth to participate and contribute meaningfully to social change processes in the conduct of an election. Also, doom youth theory tends to influence the seeming absence of sound policies and programmes for inclusion of youth in the mainstream political participation, and the harnessing of their potential for improvement in the conduct of credible elections. Instructively, a few scholars such as Mutisi (2012), Boyden and De Bery (2004), Thorup and Kinkade (2005), and Sommers (2006) have recognised the potential and asset value of youth in bringing about social change processes in their countries. As a social spectrum, youth are associated with certain traits such as exuberance, dynamism, willingness to take risks, flexible thinking and the desire for quick results (Obasanjo \& Mabogunje 1991). According to the National Youth Development Policy of Nigeria (2001, p. 1), 
Youth is the foundation of a society. Their energies, inventiveness, character, and orientation define the pace of development and security of a nation. Through their creative talents and labour power, a nation makes giant strides in economic development and sociopolitical attainments. In their dreams and hopes, a nation founds her motivation; on their energies, she builds her vitality and purpose. And because of their dreams and aspirations, the future of a nation is assured.

In consonance with the emerging notion of youth as an asset for shaping national development, this paper focuses on the political engagement of young people in the 2015 general elections in Nigeria. Constructive engagement by young adults depends on what has been described as their 'structural luminality'. Structural luminality means that in most situations in society, youth can easily navigate through and take advantage of emerging socioeconomic opportunities. They have the time, skills and motivation for activism. Hence, they are considered a valuable constituency (Editorial 2011). This paper discusses how the youth is becoming mature and is committed to bringing about change in Nigeria - a country that the US Department of Intelligence predicted as being on a path to perdition or disintegration (Adedoja 2012).

\section{HISTORICAL OVERVIEW OF NATIONWIDE ELECTIONS BEFORE 2015}

Since 1959, questions have been raised about election integrity in Nigeria. Pre1959, after the introduction of elective principle under the Clifford Constitution of 1922, elections were restricted to Lagos and Calabar, and franchise was exercisable only by adults who owned at least GB£100 (Azelama 2010). Suffrage was later extended to the other regions of the country under the Richard Constitution of 1946. However, even in areas where elections were held, the adoption of the adult suffrage excluded young adults from the electoral processes.

In preparation for independence, the first nationwide direct elections were held in 1959. The elections constituted the basis for the formation of a postindependence central government. The elections were said to be characterised by cases of violence, intimidation and repression (Diamond 1988). In the subsequent federal and regional elections, held in 1964 and 1965 respectively, there were allegations of widespread irregularities and rigging, molestation of electoral officials, abduction of candidates, and use of security agents to intimidate voters and facilitate election malpractices. Areas thus affected included parts of the midwestern, western and eastern regions. The results of the elections were rejected 
by the opposition, which subsequently resorted to violence, killing, arson, looting and the destruction of property; these events took place particularly in the southwestern region.

The youth, being the most energetic sector of the population, dominated the violence associated with electoral processes. On the basis of impropriety in the election, President Nnamdi Azikiwe delayed the reappointment of Alhaji Tafawa Balewa as prime minister. This move sparked a constitutional crisis, which required the intervention of the court and political negotiations before peace could be brokered. These interventions ensured the formation of a broadbased government headed by Balewa (Osaghae 2002). But the attendant crises, disillusionment, disenchantment and loss of confidence in the government - which was felt by most of the population - significantly motivated the military to usurp political power on 15 January 1966.

After 13 years of military rule, Nigeria was returned to civil rule through nationwide elections held in 1979. In the lead-up to the 1979 elections, measures aimed at overcoming the shortcomings of the elections in the First Republic were introduced. One such measure was the constitutional requirement of a nationwide presence in 13 out of the 19 states as part of the criteria for party registration. Another was that the person to be elected as president, in addition to securing the highest number of votes cast, was required to receive a minimum of $25 \%$ of votes cast across two-thirds of the 19 states. These reforms were aimed at social engineering and national integration against the backdrop that electoral mobilisation for support in the First Republic had taken place along ethnic and religious lines (Ogbeidi 2010). However, the declaration of the winner in the 1979 presidential election was allegedly questionable and controversial. It took the intervention of the Supreme Court and an alleged conspiracy by the departing military regime for the issue to be laid to rest.

Four years later, in 1983, another general election was held during the Second Republic. The conduct of the elections was characterised by the misuse of power of incumbency, money influence, thuggery, violence, massive rigging, irregularities, falsification of results and other malpractices. The Federal Electoral Commission (FEDECO), police and other state agents allegedly colluded with the ruling party - the National Party of Nigeria (NPN) - to commit electoral fraud. The results of the elections were hugely disputed. Virtually every assembly and governorship election result was the subject of litigation at tribunals and courts (Osaghae 2002). A few of the fraudulent election results were upheld in court on technical grounds.

Because the courts could reverse only a few cases of the disputed election results, this period was characterised by tension, uncertainty and insecurity. In some states, such as Ondo and Oyo, the governorship elections had given rise to 
many cases of arson and murder (Osumah \& Aghemelo 2010). Consistent with the doom youth theory, the youth dominated this violent engagement.

Because the nation was on the edge of a precipice, the military intervened quickly in the political sphere on 31 December 1983. Between 1983 and 1999, the military once again dominated Nigerian politics. However, within this period, there was a convoluted transition programme to return Nigeria to civil rule yet again in the so-called Third Republic. Certain measures were put in place to ensure transparent and credible elections. These included the registration of two new parties, namely the National Republican Convention (NRC) and Social Democratic Party (SDP); the banning of discredited politicians; and the use of an open ballot system. In addition, two bodies were established to inculcate civic education of democratic culture in Nigerian politicians and voters (who are predominantly young adults). These were the Directorate of Mass Mobilization for Self-Reliance, Social Justice, and Economic Recovery (MAMSER), and the National Orientation Agency.

Within this period, elections were held for the legislative assemblies at state and federal levels as well as for the offices of state governors. Finally, on 12 June 1993 the presidential election, which was the last of the staggered elections in the prolonged transition programme, was conducted. The election was described by many observers as having been the freest and fairest in the annals of Nigerian political history. Nonetheless, the Babangida regime cancelled the results of the election based on allegations of corruption, bribery and malpractices. These allegations by the Babangida regime were regarded as a flimsy excuse because they contradicted the reports by participants and observers of the election. Moreover, the election outcome represented far stronger social engineering and greater national integration compared with any of the elections that took place during the First and Second Republics. The presumed winner of the election, Chief MKO Abiola, had secured popular support across regional and ethnic divides (Bolaji 2015).

The annulment of the election result generated resistance and civil disobedience across many parts of the country. This resistance was led by youth organisations such as the National Association of Nigerian Students (NANS) and other prominent civil society groups. More than 100 protesters were believed to have been killed by the military and anti-riot police squad during street protests. Some youth groups formed to rally support for the government (Osaghae 2002). However, lumpen or 'expendable' youth participated in civil disobedience and riots, as this offered them the opportunity to break into public and private offices to remove valuable property.

As Nigeria moved toward its Fourth Republic, in December 1998 major transition institutions were established. These were the National Electoral 
Commission of Nigeria (NECON), chaired by SK Dagogo Jack, and the Transition Implementation Committee chaired by Mr Justice Mamman Nasir (Osaghae 2002). Thereafter, five political parties were registered. A major threat to General Sani Abacha's transition was the politics of self-succession. To realise his goal, Abacha and his agents deployed coercive measures such as intimidation, blackmail, detention and assassination against internal opposition. They also coerced the support of members of the political class who formed the five parties to adopt Abacha as a consensus candidate for the presidential election in August 1998. In addition, 18 youth organisations, including the National Council of Youth Association (NCYA) and the Youth Earnestly Ask for Abacha (YEAA), rallied support for Abacha's self-succession bid in Abuja (Akinboye \& Anifowose 1999). In 1998, YEAA, led by Daniel Kanu, organised a so-called 'march of 2 million' people in Abuja. In reality, the march was attended by 200000 people. The attendees comprised 'rented' youth and some civil servants, who had been threatened by state military administrators with being fired if they failed to represent their states and local governments at the march. The attendees were provided with free transportation and accommodation. The organisation of the march cost the government between $\$ 400$ and $\$ 500$ million (US\$6.2 million).

The march was aimed at pressurising Abacha to continue in office. He did so until his sudden death in June 1998 (Research Directorate, Immigration and Refugee Board Canada 1998). This type of participation fits into the first tier of the dual motivation theory. It is also consistent with assumptions of the doom youth theory, as most attendees of the march were manipulated or coerced to participate in the march.

Following the death of Abacha, his successor, General Abdulsalami Abubakar, restarted the transition to the Fourth Republic in 1998. Guidelines were set for political parties to participate in the electoral process. Part of the guidelines required political parties to accept the principles of power-sharing, rotation of key offices and an active presence in at least 24 states of the federation (Ogbeidi 2010). Nationwide elections were held in 1999 for offices of state and federal assemblies, state governors and their deputies, and the president and vice president. The 1999 elections were characterised by widespread electoral abuses such as horse-trading, undisguised financial inducement of voters, stuffing of ballot boxes with pre-marked ballot papers, snatching of ballot boxes, falsification of election results and violence (Osumah \& Aghemelo 2010). For example, while international observers estimated the voter turnout at 20\%, the results indicated between 30\% and 40\% (Ogbeidi 2010). According to Jimmy Carter, head of the election monitoring team,

there was a wide disparity between the number of voters observed at the polling stations and the final result that has been reported from 
several states. Regrettably, therefore, it is not possible for us to make an accurate judgment about the outcome of the presidential election (Ogbeidi 2010, p. 51).

The opposition party - the All People's Party (APP) - rejected the results of the presidential election on account of brazen electoral fraud, and went to court to contest the outcome. Although the court threw out the lawsuit, the APP buckled only under great pressure and appeals from Nigerians and the international community to accept the election results, simply to avert a replay of the bitter experience of another annulment (Osumah \& Aghemelo 2010). Arguably, these unconventional and antisocial behaviours were particularly associated with the lumpen youth, who were readily manipulated by desperate politicians.

Four years later, in 2003, general elections were held. The conduct of the 2003 general elections was progressively worse than the 1999 nationwide elections. As part of the preparations for the conduct of the 2003 general elections, the 2002 Electoral Act was introduced. The Act made provision for, among others, the manner in which political parties can source or receive their funds and the extent to which political parties can incur electoral expenses. This was rarely enforced. Other reform measures included registration of new parties, which increased the number of parties from three to 30, and computerisation of voter registration to keep a check on manipulation and fraudulent practices (Osumah 2010).

Despite these measures, the conduct of the election was largely unsuccessful. Both international and domestic observers roundly described the conduct of the elections as a travesty of electoral democracy. The malpractices that characterised the conduct of the elections generated massive protests from organised labour, civil society and opposition parties. Leaders of the opposition parties rejected the outcome of the election and called for the formation of an Interim National Government of Unity. More than $56 \%$ of the 2003 election results were challenged in courts (Osumah 2010).

Notably, the youth were recruited and mobilised to execute some of the violent and corrupt activities. Preparatory to the elections, there was a general apprehension about the recruitment and arming of militia groups as a political machine to harass and intimidate political opponents, rig the elections, commit brigandage and organise violent protests. For example, major opposition politicians in Abia and Anambra States alleged that the incumbent governors in those two states were using the Bakassi Boys to settle political scores. The Bakassi Boys was a vigilante group made up mainly of youth. There was indeed a general apprehension that the vigilante group was being manipulated by governors to rig their re-election, or to safeguard against being rigged out in their re-election bids. Although the governors attempted to deny the allegations of manipulating 
or politicising the vigilante group, the leadership of the Bakassi Boys in Abia alleged that factions from both the APP and the People's Democratic Party (PDP) in the state had approached the group for support. In Anambra, the attempt to use the Bakassi Boys to stop the state chapter of the Nigeria Labour Congress (NLC) from a strike action over government failure to pay workers' salaries for four months was a pointer to the politicisation of the vigilante group (Ukiwo 2002). Similarly, in Rivers State, preparatory to the 2003 general elections, the Niger Delta Vigilante and the Niger Delta People's Volunteer Force were sponsored and armed by leading politicians in the ruling PDP (Chigbo 2004).

In addition to the politicisation and manipulation of militias, youth engagement in the electoral processes was partly shaped by the phenomenon of consensus candidates in the internal politics of major parties. This was dominated by the political class or by the imposition of exorbitant fees for nominating candidates for elective positions (Osumah 2010).

The conduct of the 2007 general elections was similar to that of the 2003 nationwide elections. Indeed, the conduct of the 2007 general elections was reportedly worse than that of the 2003 nationwide elections. The contest for the election was regarded by the ruling PDP as a do-or-die battle. International and domestic observers described the election as a 'rape of democracy'. Flurry allegations of impropriety - presumably perpetrated by the lumpen youth trailed the election results. A total of 1290 petitions were filed at election tribunals to litigate against the declared results by INEC (INEC Report 2011). The courts reversed some of the disputed cases. President Umaru Musa Yar'Adua, even as a key beneficiary of electoral fraud, during his inauguration speech acknowledged that the conduct of the 2007 general elections did not satisfy the conditions of best practices. He then expressed the desire for electoral reform.

Under President Yar'Adua, the Electoral Reform Panel was constituted and was chaired by former Chief Justice of the Federation, Justice Mohammed Uwais. The Panel made recommendations to improve the quality of elections. Following the death of Yar'Adua in 2010, President Goodluck Jonathan became president and continued with the introduction of measures to ensure quality and integrity-driven elections. One such measure was the appointment of Attahiru Jega, a professor of political science reputed for integrity and honesty, who was also a member of the Uwais Panel (Bolaji 2015).

Under Jega's leadership, INEC initiated various reform measures. These included an open and transparent review of voter register, strategic partnership with National Youth Service Corps (NYSC) and renewed modification of the open ballot system. The INEC also introduced security measures to protect ballot papers and ballot boxes, such as colour-coding and serial numbering. In addition, new systems of collating and transitioning results were adopted (Bolaji 2015). 
Arguably, these measures made a difference between the 2011 general elections and other elections that had taken place after Nigeria re-democratised in 1999. In particular, they minimised election-related malpractices, petitions and litigation cases. A total of 731 petitions were filed at various election tribunals across the country, which although high was 57\% lower than the 1290 registered after the 2007 nationwide elections (INEC Report 2011). However, the new measures did not prevent post-election violence in 2011, which claimed 800 lives (NDI 2012). A greater proportion of participants in the post-election violence were the lumpen youth.

In the context of the dual motivation theory, in the elections prior to 2015, youth political engagement was in consonance with the first tier of participation, namely the desire to change the election outcome for the fulfilment of a certain goal. Also, youth political engagement in elections before 2015 largely reflected the assumption of the traditional doom theory of youth bulge, youth in crisis or lumpen youth culture.

\section{SIGNIFICANCE OF 2015 ELECTION AND MEASURES TO ENSURE ITS SUCCESS}

The 2015 general election was significant in various regards. The election was critical to the consolidation of Nigeria's democracy. It was the first general election after 100 years of Nigeria's existence as a nation by reason of the 1914 amalgamation of the Northern and Southern Provinces. Also, the election was the fourth consecutive nationwide election under the civilian administration since the end of the last phase of military rule on 29 May 1999. Furthermore, the election was aimed at electing the president and members of the legislatures, at the federal and state levels, as well as governors of the 36 states of the federation except in seven states (Anambra, Bayelsa, Edo, Ekiti, Kogi, Ondo and Osun). These seven governors' tenures had been altered by judicial pronouncements in earlier elections (INEC 2014).

In addition, the election took place when Nigeria was torn between opportunity and crisis, possibly more than ever in Nigeria's post-independence history. Nigeria, apart from being Africa's most populous country, is a leading contributor in peacekeeping operations and the management of epidemic diseases such as Ebola. Despite this great potential, the country is blighted by poverty, unemployment, infrastructural deficit and insecurity. This scenario meant the elections carried a high stake - or opportunity for change-in governance, security and economy (Thurston 2015).

The election was also a test case for reaffirming the unity of the nation and for reiteration of faith in democracy and a determination to fully join the free 
world, where only the people constitute the foundation of governance. This was particularly important as many Nigerians believed that the United States Intelligence Department had predicted 2015 as a 'doom' year for Nigeria as a corporate entity (Adedoja 2012). Although the United States denied this allegation, there was heightened attention by the international community towards Nigeria's conduct of the 2015 elections. The elections thus offered an opportunity for Nigeria to register its presence among civilised nations in terms of the conduct of a credible election. This was against the backdrop that since the restoration of multiparty democracy in Nigeria in 1999, the conduct of virtually all the country's elections prior to 2015 had largely been a travesty. Apart from the 2011 elections, the general elections of 1999, 2003 and 2007 were considered by international observers as hugely flawed (Bolaji 2015).

Furthermore, the 2015 elections were considered to be important for the whole of Africa. In a letter to President Jonathan, Prime Minister of Britain David Cameron stated as follows: 'As Africa's biggest democracy, successful elections in Nigeria are important not only for Nigeria's future but as a signal to the rest of Africa' (Onuah \& Payne 2015).

In view of the importance of the elections and challenges arising from the conduct of the 2011 and other earlier general elections, INEC introduced antirigging measures such as Permanent Voters Card and Card Reader devices in the conduct of the 2015 general elections. Two peace accords were signed by the presidential candidates for the elections to show their commitment to peaceful elections. The first peace accord - organised by the Offices of the National Security Adviser and Adviser on Inter-Party Affairs to the President, and the National Institute for Policy and Strategic Studies with support from the United Nations Development Programme (UNDP) - was signed in January 2015 by the 11 presidential candidates. This showed their commitment to peaceful elections and the proper management of reactions to the results of the polls (Ezea 2015). The second peace accord was signed by presidential candidates of the All People's Congress (APC) and People's Democratic Party (PDP), Muhammadu Buhari and Goodluck Jonathan respectively. It was organised by the National Peace Committee under the Chairmanship of former Head of State, Abdulsalami Abubakar (Onuah \& Payne 2015), and signified the renewal of the candidates' pledge to peaceful elections. This trend was replicated for governorship candidates in various states. For instance, there were peace pacts among governorship candidates in Akwa-Ibom, Kwara and Rivers States (Ashameri 2015, Azubuike 2015).

In addition to the peace accords, there were diplomatic calls from Western powers who appealed to the two main presidential candidates not to stoke tension. In March 2015, United States President Barack Obama issued a direct appeal for 
calm. In a letter to President Goodluck Jonathan, British Prime Minister David Cameron called for transparent and non-violent elections (Onuah \& Payne 2015). Furthermore, stakeholders such as the media, security agencies, the Economic Community of West African States (ECOWAS), the African Union and the United Nations (UN) played various roles in ensuring peaceful elections. Among these formal and diplomatic measures were youth initiatives aimed at ensuring peaceful 2015 general elections. While this article focuses on the youth's political engagement, it is difficult to be certain how much the various measures ensured the success of the elections.

\section{ELECTIONS AND PARADIGM SHIFT IN YOUTH POLITICAL ENGAGEMENT}

Before the 2015 elections in Nigeria, the youth had not been innocent bystanders of social change. They had been innovative, creative and active participants in political processes. In many parts of the world, youth have played a progressive role. They were part of the struggle against repressive regimes in North African countries and the Middle East, such as Syria and Bahrain. The youth were involved in the anti-apartheid struggle in South Africa. In Liberia, youth played a commendable role in the conduct of the 2015 election.

The active role and potential of the youth to contribute to socioeconomic and political development has been recognised by international bodies such as the UN. The UN, through its Department of Economic and Social Affairs, has recognised that young people possess innovation, energy, enthusiasm and exuberance. A study in 2005 on the election in Liberia showed that $54.6 \%$ of the 1.3 million registered voters were young adults. Youth groups in Liberia have demonstrated an awareness of the potentially explosive consequences of politically motivated violence. Preparatory to the 2011 presidential election in Liberia, youth groups such as Liberia Youth Christian Men Association were involved in peace education (Mutisi 2012). Ismail et al. (2009), in a study conducted in Liberia, Ghana, Guinea, Liberia, Mali, Niger, Nigeria and Sierra Leone in the West African sub-region, showed that over $70 \%$ of the youth expressed faith in democratic elections as a means of bringing about regime change (Mutisi 2012).

With regard to the conduct of the 2015 general elections, youth engaged in various political activities aimed at ensuring the success of the elections. These engagements included peace promotion, popular participation, political education, election monitoring and polling administration. These youth engagements contrasted sharply with the roles of young adults in earlier elections as represented by the doom youth theory. 


\section{ELECTION ADMINISTRATION}

This was one of the most commendable roles of the youth in the conduct of the 2015 elections. This role was ostensibly executed through the NYSC. Although INEC was statutorily charged with the responsibility of administering the elections, the commission had inadequate manpower to cover the election unaided. NYSC members were recruited as ad-hoc staff to assist in the administration of polling stations, on the basis of the strategic collaboration between the NYSC and INEC (This Day 2015). INEC estimated that about 750000 ad-hoc staff were needed to conduct the election (The Punch Editorial 2015). The NYSC corps members constituted a significant proportion of the personnel in all 36 states.

The NYSC members demonstrated great courage and resilience during voter registration and polling-unit operations. Their resilience was particularly tested by mammoth crowds that were sometimes unruly, impatient, discontented and violent, following widespread challenges with card readers on election days. In the spirit of selflessness and patriotism, corps member operating polling units had to work late into the night. Indeed, international observers such as the African Union Election Observation Mission (AUEOM) and National Democratic Institute reported that corps members who served as ad-hoc polling personnel were highly professional and effective (AUEOM 2015, NDI 2015).

These young adults often performed their duties at great risk to their lives. Although no corps member was reported to have died in the conduct of the 2015 elections (in contrast to the 2011 elections in which 10 died), they were targets of politically motivated attacks. In the presidential and national assembly elections in 2015, some corps members were reportedly targets of politically motivated assaults in Ijiam ward, Ikwo LGA of Ebonyi State (CDD Report 2015). Arguably, the participation of the youth in the administration of elections at the risk of their lives marks a paradigm shift away from the doom theory and epitomises the second type of participation in the dual motivation theory, which is driven by the call to duty for one's country.

\section{PEACE PROMOTION}

The lead-up to the 2015 general election generated much tension and uncertainty, perhaps owing to hate-campaigns, bickering and desperation among politicians. This situation was reminiscent of the events that had preceded the election and post-election violence in 1965, 1983, 2003, 2007 and 2011 general elections. Realising that youth in Nigeria are the instruments and victims of politically motivated violence, youth organisations across the country campaigned for a peaceful election. Youth organisations that were actively involved in peace 
campaigns included the Youth Initiatives for Advocacy Growth and Advancement (YIAGA), the Youth Alliance on Constitution and Electoral Reform, Niger Delta Coalition for Change (NDCC), the Young-stars Development Initiative (YDI) and the Commonwealth Youth Council (CYC). These youth groups initiated various programmes to educate young people about non-violent participation and urged politicians not to use youth to commit acts of violence or political hooliganism before, during or after elections. Some youth leaders representing youth faith groups, civil society and youth development organisations met on 3 February 2015 in Abuja and signed a Youth Peace Accord. They undertook to refrain from and prevent violence during and after the election (Jozwiak 2015, NDI 2015, Sahara Reporter 2014).

One of the most prominent youth campaigns for peaceful election was led by a music icon called 2Face Idibia together with the YDI. The campaign's slogan was 'vote not fight: election no be war'. The campaign encouraged youth to make active, positive and peaceful contributions to the 2015 general elections. As a sign of commitment to peaceful elections, the campaign encouraged Nigerian youth to sign the official pledge to vote rather than fight: 'I want a peaceful Naija, therefore I pledge to vote and participate positively in the elections' (Sahara Reporter 2014).

Most other peace campaigns were conducted by youth groups from various ethnic backgrounds, although people's backgrounds played a marginal role in their campaigns. They expressed and manifested their opinions in different ways and through various media. For example, the NDCC opposed the threats by some prominent Niger Delta ex-militants to unleash violence on the country if former President Goodluck Jonathan was not re-elected (News Express 2015). Also, youths in northern Nigeria under the aegis of Arewa Youth Consultative Forum (AYCF) and their South-South counterparts of Ijaw extraction - who were both supporters of the leading presidential candidates - agreed to prevent any form of violence in the country during and after the elections (Eziukwu 2015).

The effects of the activities of these youth organisations are difficult to measure. However, compared with prior elections, wherein young adults were manipulated by politicians to execute violence, the youth increasingly played a vital role in underscoring the importance of peaceful conduct in the 2015 elections. The relatively low number of casualties from violence associated with the 2015 elections indicates the positive outcome of youth peace campaigns coupled with other peace accords. In 2003, more than 100 young people were killed in election violence between May and June. In 2007 and 2011, 300 and 800 young persons respectively were reportedly killed in election-related violence (Jozwiak 2015). In 2015, more than 160 people were reportedly killed (EUEOM 2015).

In the face of fading hopes on account of harsh socioeconomic conditions, the initiatives undertaken by the youth represent efforts to build bridges across 
ethnic lines, and to transform the prebendal and predatory social structures of successive flawed elections. Furthermore, these initiatives by the youth - despite their marginalisation and exclusion in key decision-making processes - were an expression of their hope in an ability to engender change in the electoral processes. This example is worthy of emulation by lumpen youths who are often recruited and manipulated by desperate politicians to perpetrate violence in an electoral contest.

\section{POLITICAL EDUCATION}

Voter education can make a major contribution to electoral integrity, through a dissemination of balanced and objective information on what citizens need to know to exercise their franchise. Towards the conduct of the 2015 elections, the youth independently and through partnership with INEC were actively involved in voter education. Most youth groups were secular in outlook, with no primordial background playing a role. They had either single or unified political agendas, but represented a broad spectrum of diverse views. They were mainly involved in raising awareness about electoral matters.

Youth groups such as the CYC and AYCF were actively involved in voter education. They urged youth to register with political parties, register as voters, collect their permanent voter cards and defend their votes (Jozwiak, 2015; Sahara Reporter 2014). For example, CYC educated youth on their civic rights and organised public debates on national issues across the country (Jozwiak 2015). Voter education by the youth on issues of national importance was felt more keenly in the social media, although the media was also used to hurl personal, ethnic and religious slurs at one another. The cyberspace was often dominated by hate-campaigns, mudslinging and ethnic politics.

At the same time, the leading presidential candidates realised that young people represented agents of change, as reflected in campaign appeals aimed at young adults for the 2015 election. This was understandable because the youth, who constitute the largest demographic sector in Nigeria, were key voters in the election. Through their numerical strength and being the major attendees at campaign rallies, young people were the focus of campaigns and mobilisation for electoral support. The two leading presidential candidates, Goodluck Jonathan of the PDP and Muhammadu Buhari of the APC, appealed to the youth for support. While Jonathan pointed out that as a younger candidate he would represent the youth better, Buhari promised to tackle youth unemployment, corruption and security challenges. Buhari recruited 25000 college graduates to assist in his campaign (Nwosu 2015). 


\section{ELECTION OBSERVATION AND MONITORING}

Electoral observation and monitoring have become an integral part of democratic electoral processes in Africa. Election monitoring plays an important role in enhancing the transparency and credibility of elections and democratic governance as well as acceptance of election results. It also helps to diminish conflict before, during and after elections (International IDEA 1999). Youth organisations were actively involved in observing and monitoring the electoral process. The AUEOM acknowledged this role of the youth (AUEOM 2015). As election monitors, they helped to deter fraud and encourage peaceful conduct across the country. Their monitoring initiatives promoted local ownership, boosted citizen participation and confidence in the electoral processes and reinforced the credibility of the election.

Although the youth played laudable roles in the success of the 2015 elections, there were a few instances where some youth engaged in acts that were destructive. The threat of war by some Niger Delta youths to unleash violence on the country, the hurling of stones on the convoy of President Jonathan in Bauchi and Katsina, and violent attacks in Rivers and Plateau States were clearly destructive (Chidiogo 2015; International Crisis Group 2014).

In the context of dual motivation theory, youth groups that participated in issuing threats to unleash violence on the nation if the former president lost, or who threw stones on the convoy of former president and conducted other violent attacks, arguably participated on the basis of the first tier of the dual motivation theory. By contrast, youth groups that participated actively in the areas of polling unit operations, peace-promotion activities, election observations and monitoring, as well as voter education in the conduct of the 2015 elections, arguably were driven by the second tier of participation.

\section{DRIVERS OF POSITIVE YOUTH ENGAGEMENT IN ELECTIONS}

A number of explanations can be constructed for the paradigm shift in the Nigerian youth political engagement in the conduct of the 2015 general elections, compared with prior elections. One of the major factors central to the largely constructive youth political engagement in the conduct of the 2015 general elections was their growing consciousness about the reality that they are the locomotive engine of progress in any nation - on account of their greater numerical strength, exuberance, creativity and impressionability to drive growth and development. Without the popular support of the youth, it would be difficult for any political office seeker to gain access to power through either conventional or foul means. In elections prior to 2015, most members of the Nigerian political class had 
leveraged on the gullibility of the youth to whip up primordial sentiments or had used financial inducement to lure them into violent political engagement. Indeed, in those past elections, political ethos had been so underdeveloped and awareness was at such a low ebb among Nigerians - especially the youth - that young adults exchanged their votes for small financial tokens or perks (Okhaide 1996, Osumah 2010).

Although this pattern might not have changed completely in the 2015 elections, arguably it had reduced owing to increasing awareness among the youth. The growing consciousness and realisation among the youth about their potential to bring about positive change may have been influenced by the success of the Arab Spring, which was championed by the youth coupled with the advent of social media - which has facilitated the dissemination of information, rightly or wrongly.

Another key explanatory factor for the positive youth engagement in 2015 is the unenviable record of irregularities and electoral violence and its devastating consequences. As mentioned earlier, since the advent of civil rule in 1999, there has been a progressive increase in the number of deaths of young persons in election-related violence. In 2003, 2007 and 2011 respectively, more than 100, 300 and 800 young adults were reportedly killed in election violence. In 2011, more than 65000 youth were displaced in post-election violence (Jozwiak 2015). Apart from the loss of life, destruction of valuable property, internal displacement and increasing sense of insecurity, the flawed electoral process had severe implications for democracy, respect for human rights and good governance. It affected the credibility of the democratic system. It legitimised and perpetuated the vicious cycle of the existing culture of impunity among public office-holders and scanty distribution of the dividends of democracy.

Thus a critical driver of the largely constructive engagement of the youth in the conduct of the 2015 elections was the high stake the elections carried for governance, security and economy. Prior to the elections, especially after the January 2012 subsidy riots, there had been mass disenchantment and disillusionment among Nigerian youths about the state of the nation. As shown in Table 1, the level of youth unemployment and poverty had been very high.

Table 1 shows that the youth population in both urban and rural areas of Nigeria had higher unemployment rates than other age categories. Where young adults had been made to believe that they would gain job opportunities, they were fleeced. In some government ministries, departments and agencies (at the local, state and federal levels) jobseekers were reportedly asked by unscrupulous government officials and their collaborators to pay between $\$ 200000$ and \$500 000 to secure a job (Suleiman 2013). 


\section{Table 1}

Unemployment rate (in percent) by age category in Nigeria, 2011

\begin{tabular}{|c|c|c|c|}
\hline Age Group & Urban & Rural & Total \\
\hline $15-24$ & 33.5 & 38.2 & 37.7 \\
\hline $25-44$ & 16.3 & 24.1 & 22.4 \\
\hline $45-59$ & 12.5 & 19.6 & 18 \\
\hline $60-64$ & 17.8 & 22.1 & 21.4 \\
\hline
\end{tabular}

Source: National Bureau of Statistics (2012:43), Social Statistics in Nigeria, Abuja, NBS

Many government establishments that had reportedly been involved in such practices often issued disclaimers to clear their names, and at the same time issued advice to unsuspecting job-seekers to beware of job scammers illegally using those organisations' names.

This did not discount the fact that unemployed youth went through hardship in competing for jobs when government establishments did embark on mass recruitment. A case in point was deaths recorded at venues of an interview test organised by the Nigeria Immigration Service Department in 2014. Against the high level of youth unemployment, there were huge infrastructure deficits across the country and a rising wave of insecurity, as demonstrated by the Boko Haram insurgency which has resulted in the death of over 12000 persons (Aghedo 2014).

\section{CONCLUSION}

This article has illustrated a paradigm shift in youth political engagement in the conduct of the 2015 general elections in Nigeria. Discounting the traditional youth theory of youth bulge, youth in crisis and lumpen youth culture, the paper discussed this shift from destructive to constructive youth engagement. It argued that there is a paradigm shift in the democratic attitudes of the youth, and their political and civic engagement levels in the conduct of the 2015 elections compared with prior elections. The democratic attitudes exhibited by the youth in the conduct of the recent election showed that they believe generally in the importance of having a credible election process, more than ever. Civically and politically, the youth engaged in activities aimed at ensuring more credible elections. This was reflected in the increasing number of youth groups that participated in various activities such as voter education, peaceful promotion, election monitoring and polling unit operations.

In the context of dual motivation theory, the youth political engagement level may have been low in prior elections given the nature of political mobilisation, 
exclusionary politics, and corruption of the political class in its quest for public office in Nigeria. In such a situation, where political action was severely constrained, participation in the electoral process on the basis of a duty to be involved in the public affairs of one's own country was not appealing to the youth.

The 2015 elections provided the youth the opportunity to participate in and change the political game. The motivation for this dynamic shift from destructive to constructive engagement in part included the inflammable repercussions of previous elections, the high stakes of the 2015 general elections for governance and growing consciousness of the real potential of young people to act as agents of change (with the aid of social media and given the recent success of the Arab Spring, which was driven by youth). However, young Nigerian adults can further improve their effectiveness in the conduct of future elections by constructively engaging stakeholders in the electoral process. Also, the youth can continue to use various platforms to popularise positive civic and political engagement in future elections.

\section{- REFERENCES -}

Abdullah, I \& Muana, P 1998, ‘The Revolutionary United Front of Sierra Leone: A revolt of the Lumpenproletariat', in C Clapham (ed), African guerrillas. James Currey, Oxford.

Adedoja, T 2012, 'Revealed: US never predicted Nigeria's break up by 2015', This Day, May 15.

Adejumobi, S 2000, 'Elections in Africa: A fading shadow of democracy?' International Political Science Review, vol. 21, no. 1, pp. 59-73.

African Union Election Observation and Monitoring (AUEOM) 2015, 'African Union Election Observation Mission to the 28 March 2015 presidential and national assembly elections in the Federal Republic of Nigeria', Preliminary Statement, 29 March.

Agbaje, A \& Adejumbi, S 2006, 'Do votes count? The travails of electoral politics in Nigeria', Africa Development, vol. 31, no. 3, pp. 25-44.

Aghedo, I 2014, 'Old wine in a new bottle: ideological and operational linkages between Maitatsine and Boko Haram revolts in Nigeria', African Security, vol. 7, no. 4, pp. 229-250.

Aghedo, I \& Eke, SJ 2013, 'From arms to alms: the Almajiri phenomenon and internal security in Northern Nigeria', Korean Journal of Policy Studies, vol. 28, no. 3, pp. 97-123.

Aghedo, I \& Osumah O 2014, 'Bread, not bullet: Boko Haram and insurgency management in Northern Nigeria', African Study Monograph, vol. 35, nos. 3 \& 4, pp. 204-230. 
Akinboye, SO \& Anifowose, R 1999, 'Nigerian government and politics', in R Anifowose \& F Enemuo (eds), Elements of politics, Sam Iraoanusi Publications, Lagos, pp. 238-260.

Ashameri, I 2015, 'Group hails peace pact among governorship candidates', Daily Independent, 2 March.

Azelama, JU 2010, 'Nigerian constitutional development: from the Nigerian Council to the 1963 Republican Constitution', in JU Azelama (ed), Nigerian government and politics, Ever-Blessed Publishers, Benin City, pp. 26-53.

Azubuike, V 2015, 'Rivers Guber: Dakuku, Wike, Prince will sign peace pact', Daily Post, 23 January.

Bangura, Y 1997, 'Understanding the politics and cultural dynamics in Sierra Leone War: a critique of Paul Richard's fighting for the rain forest', Africa Development, vol. 22, nos. 3/4, pp. 117-148.

Bolaji, K 2015, 'Toward institutionalizing credible elections in Nigeria: a review of reform measures by the Independent National Electoral Commission' in International Institute for Democracy and Electoral Assistance Improving electoral practices: Case studies and practical approaches, International IDEA, Stockholm, Sweden.

Boyden, J \& De Berry, J 2004, 'Introduction', in J Boyden \& J De Berry (eds), Children and youth on the frontline: ethnography armed conflict and displacement, Berghahn, Oxford, pp. xi-xxvii.

CDD Report 2015, 'CDD Report: Matters arising from voting phase of Nigeria presidential, national assembly elections', Premium Times, 29 March.

Chidiogo, E 2015, 'Opinion: The role of youth in ensuring credible elections', the Guardian, 14 February.

Chigbo, M 2004, 'Why we are fighting', Newswatch, 20 September.

Diamond, L 1988, Class, ethnicity and democracy in Nigeria: the failure of the First Republic, Syracuse University Press, New York.

Editorial 2011, 'Young lives in transition: From school to adulthood?', European Journal of Development Research, no. 23, pp. 669-678.

European Union Election Observation Mission (EUEOM 2015), Final Report, Federal Republic of Nigeria general elections 28 March 2015, 11 April 2015.

Ezea, S 2015, 'Elections 2015: The worth of peace accord', The Guardian, 27 March. Eziukwu, A 2015, 'Niger Delta militants meet in Yenagoa, threaten war should Jonathan lose presidential election', Premium Times, 24 January.

INEC Report 2011, 'Report on the 2011 general elections' Available at: http:/ / www.inecnigeria.org/wp-content/uploads/2013/07/REPORT-ON-THE-2011-GENERAL-ELECTIONS.pdf INEC 2014, 'Time table and schedule of activities for general elections, 2015', 14 January, Available at: http:/ / www.inecnigeria.org/wp-contentuploads / 2014/02/General-Elections, pdf accessed 11 July 112015. 
International Crisis Group 2014, 'Nigeria's dangerous 2015 elections: limiting the violence', Africa Report, no. 220, 24 November.

International IDEA 1999, 'The future of international electoral observation: lessons learned and recommendations', Newsletter 13, September.

Ismail, W Olonisakin, F Picciotto, R \& Wybrow, D 2009, Youth vulnerability and exclusion in West Africa: Synthesis report, Conflict, Security and Development Group (CSDG) paper no. 21, King's College, London.

Jega, A 2007, Democracy, good governance and development in Nigeria, Spectrum Books Limited, Ibadan.

Jozwiak, G 2015, 'Young people lead fight for peaceful elections in Nigeria' Devex 26 March, https: / / www.devex.com/ news/young-people-lead-the-fight-forpeaceful-elections-in-nigeria-85752 Accessed 11 July 2015.

Mutisi, M 2012, Interrogating traditional youth theory: youth peacebuilding and engagement in post-conflict Liberia, African Centre for the Constructive Resolution of Disputes, South Africa.

National Democratic Institute 2012, Final report on the 2011 Nigerian elections, National Democratic Institute for International Affairs, Abuja.

National Democratic Institute 2015, Statement of the National Democratic Institute's International Observer Mission to Nigeria's March 28, 2015 presidential and legislative elections, National Democratic Institute for International Affairs, Abuja.

News Express 2015, ‘Niger Delta won't burn if Jonathan loses 2015 presidential election, ex-militants declare', News Express, 10 March.

Nwosu, C 2015, 'Nigeria's youth factor', Foreign Policy in Focus, 29 April. Available at: http: / / fpif.org/nigerias-youth-factor/

Obasanjo, O \& Mabogunje, A 1991, Elements of development, African Leadership Forum, Lagos.

O'Brien, DBC 1996, 'A lost generation? Youth, identity and state decay in West Africa', in RP Werbner \& T Ranger (eds), Postcolonial identities in Africa, Zed Books, London.

Ogbeide, FO 2013, 'Youths' violence and electoral process in Nigeria's Fourth Republic: a case study of Ota, Ogun State, Nigeria', International Journal of Education and Research vol. 1 no. 9, pp. 1-14.

Ogbeidi, MM 2010, 'A culture of failed election: revisiting democratic elections in Nigeria, 1959-2003', Historia Actual Online, no. 21, pp. 43-56.

Okhaide, PO 1996, 'Political parties and pressure groups', in PO Okhaide (ed), Nigerian government and politics: an introduction, OshiokeYakubu (Nig.) Enterprises, Lagos.

Olujide, MG 2008, 'Attitude of youth towards rural development projects in Lagos State, Nigeria', Journal of Social Sciences, vol. 17, no. 2, pp. 163-167. 
Onuah, F \& Paye, J 2015, 'Nigeria's presidential candidates sign new peace appeal', The Guardian, 14 March.

Osaghae, EE 2002, Crippled giant: Nigeria since independence, John Archer, Ibadan.

Osumah, O 2010, Fundamentals of government and politics: concepts, issues and cases, Amfitop, Benin City.

Osumah, O \& Aghemelo, AT 2010, 'Elections in Nigeria since the end of military rule', Africana, vol. 4, no. 2, pp. 9-64.

Research Directorate, Immigration and Refugee Board Canada, 1998, 'Nigeria: youth earnestly ask for Abacha (YEAA)', Research Directorate, Immigration and Refugee Board of Canada, Canada.

Sahara Reporter, 2014, '2Face Idibia Leads “Election no be war" campaign', Sahara Reporter, 30 September.

Schucher, G 2014, 'Ticking time bomb? - youth unemployment problem in China', German Institute of Global and Area Studies, no. 258.

Sika, N 2012, 'Youth political engagement in Egypt: from abstention to uprising', British Journal of Middle Eastern Studies, vol. 39, no. 2, pp. 181-199.

Sklar, R 2004, Nigerian political parties: power in emergent African nations, African World Press, London.

Sommers, M 2010, 'Urban youth in Africa', Environment and Urbanization, vol. 22 no. 2, pp. 317-332.

Spinks, C 2002, 'Pentecostal Christianity and Young Africans' in A De Waal \& N Argenti (eds), Young Africa: realizing the rights of children and youth, African World Press, New Jersey, pp. 193-206.

Suleiman, T 2013, 'Robbing the jobless', Tell, February.

The National Youth Policy 2001, Federal Government Press, Lagos, Nigeria.

The Punch Editorial 2015, 'Safety of NYSC Members in 2015 elections', The Punch, 25 January.

This Day 2015, 'NYSC and the 2015 election', This Day, 22 April.

Thorup, CL \& Kinlade, S 2005, What works in youth engagement in Balkans, International Youth Foundation, Baltimore.

Thurston, A 2015, 'Background to Nigeria's 2015 elections', a report of the Center for Strategic and International Studies, January.

Ujo, AA 2000, Understanding elections: a guide for students and election managers, Joyce Graphic Printers \& Publishers, Kaduna.

Ukiwo, U 2002, 'Deus ex machina or Frankenstein monster? The changing roles of Bakassi Boys in Eastern Nigeria', Democracy and Development: Journal of West African Studies, vol. 3, no. 1, pp. 39-51.

UNICEF 2013, 'Nigeria: A country programme document, 2014-2017', draft country document for Nigeria, 6 September.

Urdal, H 2004, 'The devil in the demographics: the effect of youth bulges on domestic 
and armed conflict - 1950-2000', World Bank Social Development Papers: Prevention and Reconstruction Paper no. 14, World Bank, Washington DC. Usman, SM 2009, 'Causes and consequences of youth involvement in electoral violence', paper presented at one-day workshop on youth against violence, organised by Arewa Patriotic Vanguard in collaboration with Independent National Electoral Commission (INEC) for Youths in the Northwest Zone. Nigeria, 21 November. 